\title{
Fabricating Education through PISA? An Analysis of the Distinct Participation of China in PISA
}

\section{Candido, Helena Hinke Dobrochinski}

2020

Candido , H H D , Granskog , A \& Tung , L C 2020 , ' Fabricating Education through PISA? An Analysis of the Distinct Participation of China in PISA ' , European Education , vol. 52 , no. 2 , pp. 146-165 . https://doi.org/10.1080/10564934.2020.1759097

http://hdl.handle.net/10138/338204

https://doi.org/10.1080/10564934.2020.1759097

cc_by_nc

acceptedVersion

Downloaded from Helda, University of Helsinki institutional repository.

This is an electronic reprint of the original article.

This reprint may differ from the original in pagination and typographic detail.

Please cite the original version. 


\section{Fabricating education through PISA? An analysis of the distinct participation of China in PISA}

Helena Hinke Dobrochinski Candido ${ }^{\text {a* }}$, Anyara Granskog ${ }^{\mathrm{b}}$, and Lai Cheuk Tung $^{\mathrm{b}}$

${ }^{a}$ Faculty of Educational Sciences, University of Helsinki, Helsinki, Finland; ${ }^{b}$ Faculty of Social Sciences, University of Helsinki, Helsinki, Finland

*corresponding author: helena.candido@helsinki.fi

To cite this article: Candido, H. H. D., Granskog, A. \& Tung, L. C. (2020). Fabricating Education through PISA? An Analysis of the Distinct Participation of China in PISA, European Education, 52(2), 146-165. DOI:

10.1080/10564934.2020.1759097

\section{Acknowledgements}

We are grateful for the encouragement of Professor Tero Erkilä to develop this research; for the comments we received from Working Group 2 on "Governance, Nation State, and the New Transnational Order" at the XXVIII Comparative Education Society in Europe (CESE) Conference; for the support provided by the editors of this Special Issue; and to Vanessa Fuller for the through English-language revision. 


\title{
Fabricating education through PISA? An analysis of the distinct participation of China in PISA
}

\begin{abstract}
PISA allows for comparisons and contributes to the distribution of certain types of capital among countries, which is converted into soft power. Education has been considered an important pillar of the increased status and power China holds globally. However, Chinese participation in PISA differs from other countries, whereby only some of China's wealthiest areas participate rather than the entire country. Our research investigates China's distinct participation in PISA and its political implications through an analysis of the discourses of China and the OECD. Our findings point towards an intertwinement between local agency and global scripts regarding Chinese involvement in PISA.
\end{abstract}

Keywords: China; PISA; education politics.

\section{Introduction}

The status and power of the People's Republic of China (hereafter "China") has increased in recent years, boasting the second largest GDP in the world and the second highest growth rate. Education has been considered an important pillar to such achievements (OECD, 2016c). To keep up with the pace, the Chinese government aims to build world-class universities and improve the quality of basic education (China, 2016). Although China has occupied top positions in the latest PISA $^{1}$ rankings, Chinese participation differs from other countries since only "China's 'first-level' entities of

\footnotetext{
${ }^{1}$ The Programme for International Student Assessment (PISA) is an international comparative assessment of 15-year-old students' achievements in reading, math, and science administered in three-year cycles since 2000 by the OECD.
} 
governance" (OECD, 2016a) participate in this international large-scale assessment (ILSA). ${ }^{2}$ Such governance entities represent the wealthiest and most developed regions in China, a country facing high rates of social and economic inequality. Our paper investigates China's participation in PISA and the political implications of such engagement.

Different dynamics, primarily derived from business practices and neoliberal ideas, have been incorporated into education, such as accountability, comparability, and performativity (Hood \& Jackson, 1991; Osborne \& Gaebler, 1993; Ozga, 2009; Ball, 2012). Initiatives such as PISA, a polyglot instrument that transcends economies, global politics, and educational sectors (Steiner-Khamsi, 2019), reflect these dynamics (Grek, 2009). The OECD, the international organization that coordinates PISA, played an important role in establishing a "comparative turn" in politics, and became one of the "most powerful agents of transnational education governance" (Grek, 2009:24).

Some argue that these dynamics permeate decision-making across the globe as a world culture that diffuses general trends in education: states abide by similar normative frameworks (Meyer et al., 1997). Improving educational standards, competing for a high position in the PISA ranking, and using comparability as a governance tool represent global manifestations of the world culture. Our research, however, subscribes

${ }^{2}$ Hong Kong and Macau, special administrative regions of China, have administered PISA since 2000 and 2003, respectively. They enjoy a high degree of autonomy compared to the other regions of China, including their own governments and education systems. For this reason, we focus our research on mainland China. Hereafter, we exclude Hong Kong and Macau when we use the generic term "China" in this article. 
to a Bourdieusian approach that considers states as both determined and determining agents (Wacquant, 2007) rather than simply enacting the world culture. We claim that states have agency to accumulate different types of capital in objective and symbolic forms to compete for the distribution of power in the globalized knowledge economy. International large-scale assessments such as PISA serve as instruments to gain capital, since they render a certain degree of internationality to the participating countries. Performing well in ILSAs grants prestige and recognition to states, thereby contributing to legitimating their education policies and increasing their soft power (Steiner-Khamsi, 2019).

Power and knowledge reside in a mutually constitutive relationship, each influencing the production of discourses (Foucault, 1980). Rather than simply constituting forms of speech, discourses "are performative and produce particular versions of social reality to the exclusion of other possibilities, thereby substantially shaping socioeconomic, institutional, and cultural conditions and processes" (Greckhamer \& Cilesiz, 2014:424). They construct and legitimize certain views and beliefs, evaluate and describe social, political, and economic goals as well as realizing and instrumentalizing them (Wilkins, 2016). Thus, discourses are part of a larger whole, reflected within the existing power relations, ideologies, and practices (Foucault, 2005, 1989).

Here, we employed discourse analysis to scrutinize data from the Chinese government and the OECD about the distinct participation of China in PISA. Zhang \& Akbik (2012) argued that PISA has reformulated the education discourse in China and our research confirms that such a change does not rely on formal logic, but reaches the realms of rhetoric and politics. Our findings suggest that China's participation in PISA 
1) is troubled, surrounded with glorifying and scandalizing effects, as well as criticism;

2) sustains a mutually beneficial relationship between China and the OECD; 3) corroborates the emancipation of China's education and contributes to the fusion of East-West norms. Overall, our analysis shows the simultaneous configuration of acquiescence to and subversion of dominant ideas, which are sometimes carried out by transnational organizations (e.g., OECD) and at other times embedded in domestic (e.g., Chinese) politics. Thus, the participation of China in PISA reveals an intertwinement between global scripts and local agency.

In the next section, we introduce the theoretical background of this research. Later, we describe the data and methods we employed in our analysis. We, then, present our findings based on the three main categories of discourses manifested in the analysis. Finally, we offer concluding remarks and outline the future implications of this research.

\section{Knowledge as powerful capital in global governance}

Following a Foucauldian approach, we subscribe to the idea that knowledge is power, more specifically that power and knowledge reinforce one another (Simons, 1995). This sustains a cycle in which actors that hold legitimate knowledge are more likely to possess power and vice versa. Yet, this implies that knowledge has been transformed into a competitive advantage to access a variety of resources. Competitiveness represents a hegemonic political discourse, wherein education reform is portrayed as a means to enhance global competitiveness (Sum, 2009; Auld \& Morris, 2016). ILSAs, such as PISA, enact competitiveness, functioning as a reliable proxy for human capital and comparison of the relative positions of the competitors (Auld \& Morris, 2016). 
For competition to occur, competitors should possess some sort of capital that is widely recognized as valuable. The relationship between capital and power has been extensively studied, but the complexity of the social space requires other elements to grasp its dynamic characteristics. Bourdieu introduced other concepts of capital (e.g., cultural, social, and symbolic) beyond the economic to represent the "multidimensional space of positions" in society occupied by individuals according to 1) the volume of capital possessed, and 2) the composition and relative weight of different types of capital within their total capital (Bourdieu, 1985, 1986).

Bourdieu developed his theoretical ideas focusing on the perspective of individuals and their connection to the social space. Here, we employ his ideas to study states as social agents and holders of capital; rather than monolithic, states carry a socially inherited history (Wacquant, 2007). Bourdieu views the state more as a fieldthe administrative field within the field of power - than an agent, but argues that the state represents a kind of reserve of symbolic capitals, which is both an instrument for certain agents and the stake in struggles between them (Bourdieu, 2014). Such capitals represent instruments of power and domination. In this article, we are particularly interested in the accumulation of symbolic capital(s) through participation in ILSAs (particularly PISA).

Countries participating in ILSAs, including China, have used them for their own political interests (Rautalin \& Alasuutari, 2009; Addey et al., 2017; Waldow \& SteinerKhamsi, 2019). According to Addey et al. (2017), countries engage in ILSAs aiming to 1) collect evidence for policymaking; 2) build capacity to develop national assessments; 3) obtain funding and aid; 4) enhance international relations; 5) sustain national political agendas; 6) assess human capital, economic competitiveness, and attractiveness; and 7) gather information for curriculum and pedagogical practices. High performers in ILSAs 
such as Finland accumulate high volumes of cultural capital and prestige, becoming legitimate producers and disseminators of "best practices" (Auld \& Morris, 2016) and reference societies in other contexts to support educational reforms (Waldow \& SteinerKhamsi, 2019; Takayama et al., 2013). Additionally, states also project their accomplishments on ILSAs domestically, building coalitions, legitimizing reforms as well as bolstering national sentiments. The greater the diversity across the education system and its context, the more ambiguous and ubiquitous the enactments of ILSAs become (Addey et al., 2017).

In this sense, ILSAs fuse the global and the local, mirroring glocalization (Robertson, 1995, 1992). ILSAs seem to transmit global models that "instill agency into empowered locals, who in turn enact and thus reinforce such global scripts" (Drori et al., 2014:6). In a glocalized manner, ILSAs manifest multidimensional effects, intersecting vertical, horizontal, and temporal axes across different governance levels, spaces, and times, as a "collage of global and local components" (Drori et al., 2014:13). When enacting ILSAs, states maintain "local agency while also being current on global themes" (Drori et al., 2014, 13).

To summarize, in the globalized knowledge economy, ILSAs such as PISA 'reveal a nation's quality of education and foresee this nation's 'competitiveness' in the 'global society of the future"' (Schulte, 2019:181). Participation in PISA contributes to the accumulation of a transnationally legitimate capital, representing a significant symbolic upgrade to the international status of non-OECD members like China (Takala et al., 2018). Performing well in PISA grants countries a competitive advantage, reflecting on the intertwinement of global and local agendas. 


\section{Data and methods of analysis}

In this study, we focus on discourses from the OECD and China, the two parties involved, to understand the unique participation of China in PISA compared to other countries. We adopt the concept of discourse as knowledge formations to refer to what is "within the true", that is, how politics affects the definition and experience of reality (Foucault, 1989). We are interested in the relationships within discourses, including their symbolic and material elements, which make "things said", i.e., China's participation in PISA, legitimate and meaningful. Hence, discourses are approached as a set of "historically constructed ways of reasoning that are the effects of power" (Popkewitz \& Brennan, 1998:9). We explore China's participation in PISA without concentrating on facts and realities or differences and similarities alone, but through discourse analysis.

Our research draws on a systematic retrieval of documents referring to China's participation in PISA. To find relevant documents for our database, we retrieved the webpages of the OECD and dug into the limited notes and reports of the Chinese government on the topic. The data consist of openly accessible documents, reports, notes, speeches, and short articles about PISA in general and specifically about China's participation in PISA. The OECD documents were available in English. The Chinese government documents, however, were mostly published in Chinese and were translated to English by one of the authors of this study. Because of China's restricted information disclosure policy and given the limited data about China's engagement in PISA, we added media articles associated with the topic of this study to our database. These articles emerged following a search in Google using the keywords "China", "PISA", and "OECD". The search retrieved a large number of media articles. After scanning them, we selected those that contained direct and indirect quotations from Chinese 
authorities and OECD representatives, such as Andreas Schleicher, the Director of

Education and Skills at OECD, and OECD Secretary-General Angel Gurría. In addition

to the above-listed sources, we reviewed the relevant academic literature to

contextualize the data and the prevailing discourses due to the complexity of the topic.

The research data are summarized in Table 1 . We employed discourse analysis in the first and second sets of data; the third set of data, which served as background information about China and contributed to an understanding of some intrinsic characteristics of the relationship between China and the OECD, followed a systematic literature review to supplement our discourse analysis.

Table 1. Summary of research data sources

\begin{tabular}{|c|c|c|c|}
\hline & Sources & Roles in our analysis & Examples of references actually used in our analysis \\
\hline $\begin{array}{l}\text { First } \\
\text { set of } \\
\text { data }\end{array}$ & $\begin{array}{l}\text { OECD and } \\
\text { the Chinese } \\
\text { government }\end{array}$ & $\begin{array}{l}\text { Main data scrutinized in } \\
\text { our analysis }\end{array}$ & $\begin{array}{l}\text { China (2016); MOE (2013, 2015, 2018); OECD (2010a, } \\
\text { 2010b, 2012a, 2012b, 2014a, 2014b, 2016a, 2016b, } \\
\text { 2016c, 2017, 2018); Schleicher (2013) }\end{array}$ \\
\hline $\begin{array}{l}\text { Second } \\
\text { set of } \\
\text { data }\end{array}$ & Media & $\begin{array}{l}\text { Secondary data with direct } \\
\text { and indirect quotations } \\
\text { from OECD } \\
\text { representatives and } \\
\text { Chinese authorities used } \\
\text { in our analysis }\end{array}$ & $\begin{array}{l}\text { Chen (2016); Cook (2010); Coughlan (2014); Dong } \\
\text { (2013); Foshan Education (2016); Gumbel (2010); } \\
\text { Jiefang Ribao (2013); Wang (2013); Wang (2014) }\end{array}$ \\
\hline $\begin{array}{l}\text { Third } \\
\text { set of } \\
\text { data }\end{array}$ & $\begin{array}{l}\text { Academic } \\
\text { literature }\end{array}$ & $\begin{array}{l}\text { Tertiary data to } \\
\text { contextualize the data and } \\
\text { the prevailing discourses }\end{array}$ & $\begin{array}{l}\text { Akbik et al. (2014); Chen et al., (2015); Dahlman et al. } \\
\text { (2007); Gao et al. (2018); Han et al. (2016); Kanbur \& } \\
\text { Zhang (1999); Li \& Lu (2016); Li et al. (2013); Loveless } \\
\text { (2014); Lu et al. (2016); Ma (2010); Qiang et al. (2017); } \\
\text { Reyes \& Tan (2019); Schulte (2019); Takala et al. } \\
\text { (2018); Tan (2017); Walker (2011); Xu \& Wu (2016); } \\
\text { Zhang \& Akbik (2012); Zhang (2013); Gurova et al. } \\
\text { (2018). }\end{array}$ \\
\hline
\end{tabular}

The point of departure for our discourse analysis was inspired by the systematics of qualitative content analysis (Schreier, 2012). Our approach consisted of several iterative tasks in order to deepen the analysis of the OECD's and Chinese discourses. First, all authors read the selected documents guided by the following questions: 1) Why did 
China's case selection for PISA differ from other countries' participation in PISA?; 2) What reasons, motivations, and intentions support China's distinct participation in PISA?; 3) To what extent does such support come from the OECD and to what extent does it come from China?; 4) What effects does this varying participation in PISA entail? These questions and their answers structured the coding-frame for our datadriven analysis. Once the data were codified, we analyzed the discourses expressed in the codes, influenced by the works of Foucault. We revisited the original text in which those codes appeared to gain a comprehensive understanding of them whenever needed. The richness of the discourses we analyzed allowed us to articulate the findings into three main discursive categories, which are described in detail in the following sections. The different themes comprised in each of the categories are not clear-cut, but rather interconnected, as we discuss in the concluding part of this study.

\section{China's participation in PISA: gaining legitimate capital for global competitiveness}

The discourses manifested in our analysis of the OECD and the Chinese government data rely on both the material and symbolic practices of praise and criticism of China's participation in PISA, the mutual benefit of the relationship between China and the OECD, and Chinese emancipation from the Western ideas. Therefore, we classified our findings into three main categories of discourses. The first category concerns the issues associated with China's engagement in PISA. We depart from a macro perspective- - the operationalization of PISA, the comparability it entails, and the Chinese context - to assess the phenomenon under scrutiny, pondering the discourses that refer to the distinctive participation of China in PISA. The second category comprises discourses describing the relationship between the OECD and China and what is at stake in order 
to maintain and strengthen such a partnership. Finally, the third category relates to the local level — that is, China's domestic space—and the contradictory discourses about PISA, at times suspicious, and at other times portraying the Chinese instrumental use of PISA. We present and discuss our findings in the three sub-sections that follow, identifying how the participation of China in PISA contributes to the accumulation of legitimate capital to endure global competitiveness.

\section{China's "troubled" engagement in PISA}

As stressed above, China's participation has been shocking in many ways. The debut of the country in PISA 2009 received global attention following Shanghai's consecration at the top of the ranking in the three fields tested. This scenario repeated again in PISA 2012. Such exposure created much buzz, projecting Shanghai onto the global lens through the "glorification" and "scandalization" (Steiner-Khamsi, 2003) of PISA results and criticism towards China's engagement in PISA, which occurred both domestically and internationally, from both enthusiastic and skeptical perspectives (Reyes \& Tan, 2019; Schulte, 2019; Waldow et al., 2014; Sellar \& Lingard, 2013). Interestingly, despite Hong Kong's and Macau's constant high performance in PISA, ${ }^{3}$ Shanghai, a direct-controlled municipality, grabbed all of the international attention.

Its excellent performance was associated with successful education pre-PISA reforms in Shanghai which activated students, ultimately fostering autonomy and

\footnotetext{
${ }^{3}$ Hong Kong was among the top 10 performers on all PISA tests from 2000 to 2018, whereas Macau's scores were among the top 10 performers on math from 2003 to 2018, on science for PISA 2015 and 2018, and on reading in 2018 (OECD, n.d.).
} 
cooperation (OECD, 2010b, 2016a). The Head of the Shanghai PISA Project Team, Zhang Minxuan, expressed that the "balanced [meaning that students' and schools' scores are equally balanced] development of basic education over decades" obtained through "working tirelessly" has been rewarded by the confidence provided by the PISA results (Dong, 2013). Despite the impressive scores, reforms continued, focusing on student engagement, curriculum, and examinations, and justified by students' excessively burdensome schoolwork, lack of enthusiasm and self-confidence, limited self-directed learning, and exaggerated expectations towards schools (OECD, 2010b, 2016a, 2016c), since "Shanghai was ranked 12th in terms of academic burden" (Zhang Minxuan, in Dong, 2013). According to the Minister of Education of China, "students, especially primary and secondary school students, are overburdened with academic work", they "are not innovative and have insufficient practical skills" (Foshan Education, 2016). The Head of the Shanghai PISA Team reflected that "the good results of PISA make us confident enough to create more room for reform" (Jiefang Ribao, 2013), because "PISA is actually serving as a diagnosis" (Dong, 2013).

In total, 12 regions of China participated in PISA 2009 (Cook, 2010; Schulte, 2019), despite only disclosing Shanghai's results. Prior to 2009, only countries and special administrative regions, such as Hong Kong and Macau, took part in PISA. The participation of special regions in 2009 illustrates a novel initiative of OECD. Alongside these Chinese entities, the Himachal Pradesh and Tamil Nadu states in India, the Venezuelan state of Miranda, and the Emirate of Dubai of the United Arab Emirates (UAE) participated in PISA 2009 (OECD, 2010a). India and Venezuela participated via the PISA 2009+ project, with tests administered in 2010, following the same technical and quality standards applied to PISA 2009 participants (Walker, 2011). Dubai participated as a partner economy in PISA 2009, whereas the UAE joined PISA 2009+ 
(Walker, 2011). China's unconventional participation remained unexplained by the Chinese government and the OECD. The OECD technical report for PISA 2009 focused on PISA's sampling techniques, scaling, testing, and questionnaire design, without justifying the regional choice for the Chinese case (OECD, 2012b). No other official document attempted to provide explanations.

Despite the non-disclosure of the PISA scores from the 11 Chinese regions other than Shanghai in PISA 2009, Schleicher, representing the OECD, stated that the tests administered in rural China produced satisfactory results, approximating the average OECD scores (Cook, 2010). This discourse was spread by the international media, as illustrated by an article in Time magazine, which reported that "education in China has been spectacularly rebuilt as a modern, high-performance, and egalitarian system, at least in some cities" (Gumbel, 2010). Academic analysis of data from all 12 regions, given to a few select researchers, however, emphasized the Chinese rural-urban divide and educational inequalities (Schulte, 2019).

The reasons for not publishing the results and names of the 12 regions in the OECD reports, not even as a footnote, remain a mystery. The wish to emphasize Shanghai's education and its recent reforms were apparently prioritized, demonstrating the bargaining power of China towards the powerful OECD. This becomes clear in OECD's statements to the media immediately following the publication of the PISA 2009 results. The OECD considered Shanghai a "pioneer" (Gumbel, 2010) and a "leader" (OECD, 2010b, 2016c) in education reform. The OECD asserts that Shanghai has gone through "a sea change in pedagogy" (Gumbel, 2010).

Information remained undisclosed about the eventual participation of other Chinese regions in the following PISA tests in 2012, when Shanghai outperformed all 
other countries again. That year, 13 countries followed the example of China and engaged in regional assessments of students, differing only insofar as they all also participated in the country-wide level assessments (OECD, 2014a).

After two very successful PISA editions in 2009 and 2012, China altered its PISA participation in 2015. In addition to Shanghai, the test was administered in other Chinese regions_-Beijing, Jiangsu, and Guangdong — for which all results were disclosed. Beijing, in addition to being China's capital, is a direct-controlled municipality like Shanghai. Shanghai is the largest Chinese city based on population and the most cosmopolitan, as well as the commercial and financial center of China, while Beijing is a national cultural and education center, representing the largest science and technology research center in the country and possessing the most highly educated citizens compared to other areas in China (OECD, 2016c). Jiangsu and Guangdong are Chinese provinces, with a lower population density than the municipalities of Shanghai and Beijing, but more populous than the other provinces. These four regions, nevertheless, are far from representing all of China.

China's population, particularly with regard to income, is unevenly distributed. Its almost 1.4 billion inhabitants primarily concentrate in the major cities along the coast (UN, n.d.), bolstered by domestic migration which intensified in the late twentieth century. As such, the population living in rural China halved from 1960 to 2017, falling to $42 \%$ (WB, n.d.). China is among the least equal countries worldwide (Li et al., 2013). Rural-urban and inland-coastal inequalities widen the income gap across the country (Kanbur \& Zhang, 1999; Chen et al., 2015; Han et al., 2016).

Guangdong, the center of China's export-led manufacturing industries, is China's most populated province (OECD, 2016c). Together, Shanghai, Beijing, Jiangsu, 
and Guangdong account for $17 \%$ of the total population of the country. Shanghai and Beijing correspond to the highest incomes in China (National Bureau of Statistics of China, 2017). Guangdong and Jiangsu are among the most developed areas in China, holding the first and second highest total GDP, respectively, across all Chinese provinces (OECD, 2016c). The per capita GDP for these four regions lies above the Chinese mean. Their Human Development Index (HDI) is also high, although wealth is still far from being more equitably distributed. Shanghai, for instance, was less equal than the Chinese average in 2012 (see Table 2). Moreover, the four regions have been actively implementing educational reform pilot experiments (OECD, 2016c).

Despite intense rural migration to Shanghai, Beijing, and other coastal urban areas, education in these regions is not representative of China's education. School access remains a major concern alongside education quality, contributing to differing educational outcomes across the country. The decentralized system unequally distributes educational resources, thus poor localities are less able to offer quality educational services (OECD, 2016c). Uneven government funding schemes manifest across provinces: Guangdong and Jiangsu, respectively, invest $7.12 \%$ and $6.3 \%$ of their budgets in education, while Ningxia and Qinghai devote only $0.58 \%$ and $0.67 \%$ (Zhang, 2013). The education levels attained by children from rural areas remain lower than those in urban areas; school dropout rates are higher among students in rural areas and among individuals from rural migrant families living in urban areas (Ma, 2010). Only around $49 \%$ of the 15-year-old individuals who represent the PISA target group were enrolled in regular secondary education in $2013 ; 40 \%$ were enrolled in vocational education and 10\% were out of school (OECD, 2016c).

The OECD grouped the PISA 2015 scores of Beijing, Shanghai, Jiangsu, and 
Guangdong as "B-S-J-G (China)" or simply "China" in some reports (OECD, 2016a, 2016b, 2017, 2018). The international media and political discourses around the globe replicated this generalization following PISA 2009 (OECD, 2010b). For instance, the "B-S-J-G" aggregate data are labeled "China" in the PISA 2015 report of the UK Department of Education (Jerrim \& Shure, 2016).

The scores for the participation of "B-S-J-G" in PISA 2015, however, diverged from the top position enjoyed by Shanghai in the previous PISA editions (see Table 2). The Chinese aggregate obtained the sixth position in math and tenth in science, but ranked 27th in reading, close to the OECD mean score (OECD, 2018). The publication of the PISA 2015 results was followed by silence in China; no comments or press releases from the National Institute for Education Assessment, who oversaw PISA 2015 in China, nor from the Ministry of Education's Bureau of Education Inspections. The only publication was a short note issued by the government news agency, "Xinhua". That note indicated that "the ranking of mainland Chinese students has declined", emphasizing Shanghai's results in previous years, the outstanding scores of Hong Kong and Macau, the league winner Singapore, and the good performance of Asian countries in the PISA ranking (Chen, 2016). This might indicate that the fall in the PISA ranking was unexpected. Speculatively, it might have caused some trouble concerning China's political plans.

PISA 2015 also disclosed scores for regions within 11 participating countries (OECD, 2016b, 2018), similar to the PISA 2012 results. As previously, these countries, excluding China and Argentina, had separate scores for select regions along with the results reported for the entire country. The Argentinean case differs from the Chinese case, however; the country sample was not representative and the OECD reported only 
“Cidade Autónoma de Buenos Aires" (CABA), the capital city in PISA 2015 (OECD, 2016b). Another difference from the Chinese case is that the publication of only CABA's results in PISA 2015 was highly criticized in Argentina and internationally, whereby regional results would only be acceptable if published alongside the countrywide scores (Candido \& Acosta, 2019).

Chinese participation in PISA 2018 mirrored the PISA 2015 pattern, but the province of Zhejiang replaced Guangdong. Zhejiang is less populated than Jiangsu and Guangdong, and wealthier than Guangdong (see Table 2). As with all of the other Chinese regions participating, Zhejiang also lies in eastern coastal mainland China. The four Chinese regions participating in PISA 2018 represent 13\% of China's population. Predictions suggested that the new Chinese case selection would lead to a higher total ranking, since "Zhejiang province is known for its excellent schools and high prioritization of education among families" (Schulte, 2019:178). Along with Shanghai, the Zhejiang province also piloted the new examination reform (OECD, 2016c). The PISA 2018 results confirmed the predictions, as the aggregate "B-S-J-Z (China)" or simply "China" outperformed all other 78 participating countries and economies $(\mathrm{OECD}, 2019)^{4}$.

\footnotetext{
${ }^{4}$ This research was conducted between 2018 and 2019. The analysis did not include documents referring to the results of PISA 2018, which have been released as of the time of the final revisions of this article.
} 
Table 2. Socioeconomic indicators of Shanghai, Beijing, Jiangsu, Guangdong, and Zhejiang compared to China, and the participation of these Chinese entities in PISA

\begin{tabular}{|c|c|c|c|c|c|c|c|c|}
\hline \multicolumn{4}{|c|}{ Socioeconomic indicators } & & \multicolumn{4}{|c|}{$\begin{array}{l}\text { PISA participation (position in PISA } \\
\text { rankings) }\end{array}$} \\
\hline $\begin{array}{l}\text { Gini } \\
\text { Index } \\
(2012)\end{array}$ & $\begin{array}{c}\text { GDP per } \\
\text { capita } \\
\text { (RMB, 2014) }\end{array}$ & $\begin{array}{c}\text { HDI } \\
(2014)\end{array}$ & $\begin{array}{c}\text { \% Chinese } \\
\text { population } \\
\text { (2014) }\end{array}$ & & 2009 & 2012 & 2015 & 2018 \\
\hline 47.4 & 97370 & 0.841 & $1.78 \%$ & Shanghai & $\begin{array}{l}\checkmark(1 \text { st in } \\
\text { reading, } \\
\text { math and } \\
\text { science) }\end{array}$ & $\begin{array}{l}\checkmark(1 \text { st in } \\
\text { reading, } \\
\text { math and } \\
\text { science) }\end{array}$ & $\begin{array}{l}\checkmark \text { (6th in } \\
\text { math, 10th in } \\
\text { science, and } \\
27 \text { th in } \\
\text { reading)* }\end{array}$ & $\begin{array}{l}\checkmark(1 s t \text { in } \\
\text { reading, math } \\
\text { and science)** }\end{array}$ \\
\hline & 99995 & 0.867 & $1.58 \%$ & Beijing & & & $\begin{array}{l}\checkmark \text { (6th in } \\
\text { math, } 10 \text { th in } \\
\text { science, and } \\
27 \text { th in } \\
\text { reading)* }\end{array}$ & $\begin{array}{l}\checkmark(1 \text { st in } \\
\text { reading, math } \\
\text { and science)** }\end{array}$ \\
\hline & 81874 & 0.777 & $5.84 \%$ & Jiangsu & & & $\begin{array}{l}\checkmark \text { (6th in } \\
\text { math, 10th in } \\
\text { science, and } \\
27 \text { th in } \\
\text { reading)* }\end{array}$ & $\begin{array}{l}\checkmark \text { (1st in } \\
\text { reading, math } \\
\text { and science)** }\end{array}$ \\
\hline & 63469 & 0.761 & $7.87 \%$ & Guangdong & & & $\begin{array}{l}\checkmark \text { (6th in } \\
\text { math, 10th in } \\
\text { science, and } \\
27 \text { th in } \\
\text { reading)* }\end{array}$ & \\
\hline & 73002 & 0.769 & $4.04 \%$ & Zhejiang & & & & $\begin{array}{l}\checkmark(1 s t \text { in } \\
\text { reading, math } \\
\text { and science })^{* *}\end{array}$ \\
\hline 42.2 & 47203 & 0.738 & & China & & & & \\
\hline
\end{tabular}

Sources: Elaborated by the authors, based on OECD (2016a, n.d.), WB (n.d.), CEIC (n.d.), Global Data Lab (n.d.), and Li \& Lu (2016).

Notes:

* The position in PISA ranking refers to the scores of the aggregate "B-S-J-G", representing the test scores for the four participating regions in PISA 2015: Shanghai, Beijing, Jiangsu, and Guangdong.

** The position in PISA ranking refers to the scores of the aggregate "B-S-J-Z", representing the test scores for the four participating regions in PISA 2018: Shanghai, Beijing, Jiangsu, and Zhejiang. 
Since 2009, China has garnered much criticism regarding its distinct participation in PISA. International media had questions about cheating and whether the PISA data for China are flawed (Strauss, 2013; Dronkers, 2015; Sands, 2017). Critics imply that it neither represents the entire country since only the wealthiest regions take part nor does it represent those regions since other barriers exclude potentially poorperforming students from the tests. Such barriers include the Hukou, China's household registration system (Loveless, 2014).

The Hukou represents an institutional factor inhibiting the effects of interprovincial migration in PISA. According to that system, individuals are registered based on their place of birth and receive public services, including education, from those localities. This created a network of informal schools for migrants in Shanghai, with questionable quality and poor learning environments, given that fewer resources are allocated to them (Ma, 2010; Xu \& Wu, 2016). The Hukou system proved to be highly discriminatory not only in terms of school access and education quality, but also concerning the continuation of studies, since Chinese authorities require students to take education exams in their Hukou registration location (Ma, 2010; OECD, 2016c). In 2007, over 80,000 migrant students who were enrolled in middle schools in Shanghai had to return to their rural areas for the exams, thereby increasing dropout rates (Ma, 2010). Migrants in Shanghai can only attend vocational high school (OECD, 2016c).

The OECD responded to the criticism related to the Hukou system in 2013. Schleicher (2013) denied the previously unaddressed impact of Hukou in an article entitled "Are the Chinese cheating in PISA or are we cheating ourselves?". He states, "like many things in China, that has long changed", and continues, "as described by 
PISA, resident migrants were covered by the PISA samples in exactly the way they are covered in other countries and education systems" (Schleicher, 2013). However, the Chinese government established a nationally unified household registration system only in 2014 (effective as of 2016), whereby access to education in their place of residence is subject to a positive residence permit decision for migrants (OECD, 2016a, 2016c).

Previous research presented different arguments for the continuous participation of China in PISA since 2009: to evaluate ongoing reforms in education (Akbik et al., 2014; Reyes \& Tan, 2019), to build the capacity to develop China's domestic assessments (Schulte, 2019), to follow the recommendation of international organizations such as the World Bank (Dahlman et al., 2007), or to brand its education system for global export (Schulte, 2019). Our analysis, however, shows that instead of using Shanghai's success in PISA solely for domestic legitimacy and distinction, as argued by Schulte (2019), China seems to resort to PISA to accumulate a new sort of capital that spreads to other sectors beyond education and has become highly valuable in global politics: that is, the top position in global rankings. Such symbolic capital serves both domestic and international demands, which may have contributed to China's "notable improvement" in the country's international standing between 2011 and 2015 (China, 2016, Chapter 1). This sort of capital inflates Chinese confidence as a global player, as illustrated in the speech of Zhang Minxuan, the Director of PISA in Shanghai and Rector of Shanghai Normal University_- "since Shanghai is ranked number one in PISA, we are confident about our basic education quality" (MOE, 2013). Yet, rather than risking its own reputation, China plays the PISA "game" according to specific rules to avoid undermining its status as a powerful player in the global economy and its political agenda oriented towards domestic education reforms. This shows that China's distinction lies beyond its borders. 


\section{Sustaining a win-win relationship between the OECD and China}

As with any relationship, the relationship which exists between the OECD and China consists of two parties, each of whom has its own particular interests in terms of maintenance and growth. On the one hand, the OECD enjoys global legitimacy; but neglecting China as an active participant in its programs makes no sense, given China's economy currently challenging the global balance of power. On the other hand, because "China entered the global economy very late in the game" (OECD, 2010b), joining PISA contributes to the Chinese accumulation of capital to strengthen the country's status as a key global player.

Since the 1990s, the OECD has increased its cooperation with non-members, including central and eastern European countries and other emerging economies from the Global South. China joined the OECD as an observer country in 1996 (Takala et al., 2018). By 2007, in the face of the global economic crisis, the OECD launched the "Enhanced Engagement" program to integrate developing countries such as China into OECD's agenda (Reder, 2018). Recently, China has been considered a "key partner" of the OECD (Takala et al., 2018). Previous research also revealed that the OECD enjoys a high level of credibility and authority in China (Reder, 2018; Reyes \& Tan, 2019), whereas PISA portrays a "progressive, scientific, and advanced" education (Tan, 2017:5). The Director of the Teaching and Research Section of the former Municipal Education Commission in Shanghai, Wang Yixuan, who participated in the first experiences of Shanghai in PISA, stated that the tests "can provide a basis for the government to adjust relevant education policies" (Wang, 2013). Thus, both parties not only share interest in establishing a relationship, but also abide by certain conditions for 
it to prosper.

The OECD has praised China in many ways throughout the years of its engagement in PISA. Interestingly, that praise has exaggerated features of the Chinese context and education, while simultaneously ignoring any proper explanation. Schleicher said, for instance, that, for a developing country, China's 99.4\% enrollment in primary education and $99 \%$ in middle school stand as "the envy of many countries" (Cook, 2010). He argued that China expanded school access, and that this reflects quality, not just quantity (Cook, 2010). Scholars, however, caution that higher numbers of children remain out of school than official statistics suggest (Ma, 2010; Lu et al., 2016; Qiang et al., 2017; Gao et al., 2018).

This type of praise is also extended to Shanghai, where, according to Schleicher, high school enrollment reached 98\%, and the relevant age group achieved $80 \%$ admission rates into higher education (Cook, 2010). Shanghai's education reforms were considered outstanding when compared to other East Asian countries, reforms Schleicher regards as channeling students to innovative thought and enthusiasm, and enabling teachers, who were also better paid, to creatively adapt the curriculum (Cook, 2010). Eric Charbonnier, an education expert at the OECD, maintained that quality and equality were favored by Shanghai's reforms (Cook, 2010). In addition, the OECD reported that "Shanghai is among the cities that have dealt with migrant children with reason and sympathy" (OECD, 2010b), having constructively included migrant children in its education system (OECD, 2012a).

Wealth is unequally distributed in Shanghai (see Table 2) and migrants remain at the margins of formal schooling due to the long-lasting Hukou system. The number of migrants without a residence permit in Shanghai increased from one million to over six 
million in 2008 (Ma, 2010), corresponding to one-third of the municipal population (Shanghai, n.d.). School-aged children from rural migrant families with no Hukou registration in Shanghai were not allowed to attend school in the municipality by the time the OECD invoked its "inclusive" discourse about Shanghai.

In 2014, the OECD and China announced that they were expanding their cooperation, whereby, in addition to Shanghai, the provinces of Beijing, Jiangsu, and Guangdong would take part in PISA 2015 (OECD, 2014b). The OECD SecretaryGeneral Angel Gurría declared: "[T]his is excellent news that China is increasing its involvement in the OECD's PISA programme [sic]... It also marks another step in China's growing collaboration with OECD” (OECD, 2014b). Schleicher also expressed contentment, stating that the expansion of regions participating in PISA 2015 "marks an important stepping stone" in the relationship between the OECD and China (Coughlan, 2014).

Beyond the praise, lies the "economistic logic" of the OECD, the primary organization predicting human capital and skills in association with economic growth, and PISA, the instrument effectively measuring the (future) labor force in the globalized knowledge economy (Steiner-Khamsi, 2019). China's flagship gain from PISA is capacity building, as stated by the deputy director and inspector of the Shanghai Municipal Education Commission: "[M]ore than its result and ranking is the acquisition of a set of progressive evaluation ideologies, methods, and techniques" (Fan, 2014 as cited by Tan, 2017). These were regarded as necessary steps enabling China to assess its own education system. The OECD discourse, however, ties China's participation in PISA to economic achievements, such that the capacity building sought by the Chinese government seems closely linked to sustaining continuous economic growth through a 
well-trained labor force. Following the publication of the PISA 2009 results, the OECD attested that "just like Chinese companies, Chinese schoolchildren won't be pushed to the back of the class" (Cook, 2010). The OECD Secretary-General Angel Gurría, in relation to Shanghai's excellent performance in PISA, stated that "better educational outcomes are a strong predictor for future economic growth" (Cook, 2010).

Furthermore, Schleicher suggested that "educators in Shanghai have simply understood that the world economy will pay an ever-rising premium on excellence and no longer value people for what they know, but for what they can do with what they know" (Schleicher, 2013).

The OECD uses China as a benchmark, showcasing the example of a developing country "with moderate economic resources and in a diverse social context" (according to Gurría, in Gumbel, 2010) that succeeded in education. This reinforces the “economistic logic" of PISA, as put forth by Gurría:

While national income and educational achievement are still related, PISA shows that two countries with similar levels of prosperity can produce very different results. This shows that an image of a world divided neatly into rich and welleducated countries and poor and badly educated countries is now out of date. (Cook, 2010)

China seems willing to engage in the "economistic logic" of the OECD and PISA through capacity building, internationalization, and professionalism, which manifests in the country's five-year (2016-2020) plan for economic and social development (China, 2016). In addition, China enacts the evidence-based policymaking and comparability mindset maintained by PISA, as declared by Zhang Minxuan, the Head of the Shanghai PISA Team:

The government should guide the scientific rationality of policies according to data 
analysis. Districts, counties, and schools should carry out knowledge production on the basis of implementation. Research institutions should provide timely evidence for decision-making on the basis of international comparison (Jiefang Ribao, 2013).

Simultaneously, the OECD takes advantage of China's PISA results—by benchmarking Shanghai's results - to sustain and spread its "economistic logic" and governance models to other countries. China serves as a model to follow, which also benefits the Chinese education export business. Such discourses create a virtuous cycle, enabling a win-win situation for both the OECD and China.

Yet, the relationship between these two giants - China and the OECD—follows some conditions. Perhaps the most relevant refers to the selective disclosure of information. PISA seems to release only the minimum necessary data about China. The OECD published two chapters about Shanghai's innovative education, together with Hong Kong, in volumes on the United States (OECD, 2010b) and Japan (OECD, 2012a) that documented the lessons learned from PISA's "strong performers and successful reformers". Additionally, the OECD issued a short and a longer report, describing “China's 'first-level' entities of governance" that participated in PISA 2015 and summarizing their educational reforms (OECD, 2016a, 2016c). In contrast to a larger set of OECD publications regarding other countries - for instance, Finland, a consistent PISA top-performer, and Brazil, which continuously falls within the lower ranking positions on PISA — the limited number of reports about China and Shanghai remains striking, particularly because of the successful PISA scores.

It seems that the OECD does not disclose much data about China in keeping with Chinese government practices, which also selectively and minimally discloses information. Such alignment between the OECD and China is confirmed in one of PISA's “frequently asked questions" (FAQs) available on the OECD website: 
Why doesn't the whole of the People's Republic of China participate in PISA?

Over recent cycles, the national ministry has been piloting PISA in several provinces in preparation for fuller participation across China. Shanghai has participated since PISA 2009. Beijing and the provinces of Jiangsu and Guangdong have participated in PISA 2015. (OECD, n.d.)

As expected, the answer to this FAQ does not provide much information, showing that the OECD respects China's reservation, privacy, and information control.

To summarize, China benefits from the internationality and reputation conveyed by PISA to position itself as an important global player in education. This provides China with additional forms of capital along with its huge economic capital. The involvement of China in PISA contributes to the dissemination of the OECD's instruments and "economistic logic", and to the penetration of the OECD in the enigmatic Chinese political sphere. As Schleicher stated, "carrying out a PISA assessment in a vast and diverse country like China is a formidable challenge" (Coughlan, 2014).

\section{Emancipating China's education in an East-West fusion}

The relationship between China and the OECD, however, is not a bed of roses. Although China has participated in PISA, a large-scale national Chinese assessment is considered better than the OECD's assessment, according to Dong-Qi, the Director of Basic Education Quality Measurement Center at the Ministry of Education and the Rector of Beijing Normal University:

Chinese education measurement is more suitable and applicable [than PISA]. It is better suited for the party's educational directions and the Chinese government's standard courses. They focus on the targeted grades of students' situations and what problems the students face to improve the quality of education. (MOE, 2015) 
Since 2007, China has introduced a variety of large-scale education assessments. The first, the National Assessment of Education Quality, based on standardized tests resembling PISA and Trends in International Mathematics and Science Study (TIMSS), evaluates students' physical and mental health, and socioeconomic status in addition to reading, math, and science skills (Gurova et al., 2018). In 2012, Shanghai began piloting the so-called "green indicators", which were later converted into a nationwide assessment system, drawing from its experience with PISA (Wang, 2013). Those indicators depend less on test results and more on attitudes towards learning motivation, moral behavior, art, mental and physical health, individual development, teaching methods, school management skills, and students' socioeconomic backgrounds, in alignment with the curriculum reform (OECD, 2016c; Wang, 2013).

PISA appeared instrumental in learning how to operationalize those assessments. The chairman of the Ministry of Education's School Inspection Commission, He Xiuzhao revealed that PISA contributed to the development of an indigenous assessment system in the face of China's inability to assess education and diagnose problems (Schulte, 2019). However, Shanghai's engagement with PISA was intended to be temporary. The Head of the Shanghai PISA, Zhang Minxuan, stated that an "important reason for Shanghai to join PISA is to participate in the test and learn a set of quality evaluation and testing methods to establish a quality evaluation system suitable for Shanghai" (Wang, 2013). In other words, the goal was to learn from PISA in order to develop Shanghai's (and perhaps China's) “own scientific evaluation system in the future" (Zhang Mixuan, in Wang, 2013). This seems to have already been accomplished, but China still participates in PISA (despite its attempts to withdraw in 2015 and 2018, according to Wang, 2014 and Schulte, 2019). 
The Chinese experience with PISA — of selecting only a particular set of regions to participate in the tests—seems to follow the pattern of managing and piloting education policy and reform in the country before nationwide implementation (OECD, 2016c). The remaining question is: Will China ever participate in PISA by including the entire country? The selective participation in PISA, however, renders other benefits to the Chinese government. More than a discursive element, PISA seems to carry a nationalistic sentiment, which seems to reinforce the grandeur of the China, in its most diverse aspects, from tradition to innovation, when scores are high enough. The discourses around PISA create a wave of praise, although the OECD assessment does not necessarily act as a reference. PISA functions as a privileged discursive point, serving as a point of convergence between China's and OECD's rhetoric. In the limited public discourses about PISA, the Ministry of Education of China refers to PISA to highlight alignment with OECD's relevant competencies: “[F]rom the results of PISA, it is suggested that in math, Shanghai students' quality of concepts, standards, inferential capability, case explanation, and application abilities are high" (MOE, 2013). China's President, Xi Jinping, however, does not bother to rely on PISA to praise the government's actions in the realm of rhetoric and politics: "[T]he reformed education policy improves and encourages education to become more modernized, but, simultaneously, it maintains the Chinese traditional culture and builds up pride and cohesion among the students" (MOE, 2018). This statement aligns to the Chinese fiveyear plan, which refers to the "Chinese Dream of the rejuvenation of the nation" without weakening the core socialist values, which "have gained a firm place in people's hearts" (China, 2016, Chapter 1). To cope with that, Chinese government aims to use reform as a "powerful force for development" through "improving and developing the socialism with Chinese characteristics and modernizing the country's governance system and 
capacity for governance" (China, 2016, Chapter 2). Such orientation illustrates the potential for merging Eastern and Western norms enabled by PISA. Indeed, it appears to agree with the principle that China should maintain the "essence" of Chinese society through traditional knowledge, while using Western thought for functional purposes and practical application within its own society (Spence, 1990).

PISA encapsulates the idea of modern education across China and, therefore, may serve the purpose of renovating the "outdated" socialist regime or of highlighting the worthiness of traditional Chinese values to the world. On the one hand, the high scores in PISA 2009, 2012 and 2018 represent an alignment with Western educational models, since the OECD represents Western knowledge. On the other hand, however, Shanghai's excellent performance allows China to teach the world about Eastern knowledge through Chinese educational virtues. This is illustrated in an interview with Zhang Minxuan, the Head of PISA in Shanghai:

Yesterday [when the PISA 2012 results were launched], in an in-depth interpretation, Schleicher pointed out that there is a very clear positive correlation between study time and academic achievement; effective and reasonable use of study time will result in better academic performance.... The issue of academic burden has the cultural characteristics of China .... We all deeply agree that 'a bit of work will have a reward', so achieving a high level of academic performance must be hard work. (Jiefang Ribao, 2013)

China's Minister of Education Yuan Guiren agrees with the effect of the "hard work of Chinese teachers and students" combined with "more emphasis on basic skills training, [and] more emphasis on the development of behavioral norms" to achieve "excellent results" and cultivate "outstanding talents" (Foshan Education, 2016). But, when asked by a reporter from a Western media outlet about China's refusal to adopt textbooks entailing Western values, he responded as follows: 
Our party combines the theory of science with the reality of China and determines it as our guiding ideology.... We always put moral education first, that is, how to strengthen moral education, including the ideological and political education.... In terms of content, we emphasize persistence, firm ideals and beliefs, strengthen the education of core values, strengthen excellent traditional cultural education, and strengthen the education of the Chinese revolutionary tradition. This is our consistent policy and makes our students qualified builders of socialism with Chinese characteristics... In terms of methods, we emphasize integration and ... the combination of theory and practice to accept our excellent traditional culture and revolutionary traditional culture. (Foshan Education, 2016)

Schleicher, aware or not of a potential East-West conflict of values and practices, praises and defends China from defamation, presumably aiming to cultivate a longlasting relationship with that giant country:

\begin{abstract}
Whenever an American or European [person] wins an Olympic gold medal, we cheer them as heroes. When a Chinese does [the same], the first reflex seems to be that they must have been doping; or if that's taking it too far, that it must have been the result of inhumane training. There seem to be parallels to this in education. Only hours after [the] results from the latest PISA assessment showed Shanghai's school system leading the field, Time magazine concluded [that] the Chinese must have been cheating. (Schleicher, 2013)
\end{abstract}

The idea of appropriating Western educational thought through indigenization appears in the agenda of the Ministry of Education, which supported a national assessment system that deviates from PISA, including "soft" skills, as mentioned above. Yuan Guiren reinforces the integration of East and West norms:

We should base ourselves on China's land and carry forward our excellent cultural traditions. At the same time, we should learn to be humble. The beneficial and successful practices and experiences of all countries have made China's education better, and thus contributed to China's world class education. (Foshan Education, 2016)

This resonates with the ideas of modernization, success, and change instilled by PISA, 
as Schleicher (2013) points out:

The world has become indifferent to tradition and past reputations, unforgiving of frailty, and ignorant of custom or practice. Success will go to those individuals, institutions, and countries which are swift to adapt, slow to complain, and open to change. And the task for governments is to help citizens rise to this challenge. PISA can help to make that happen.

In this respect, PISA appears to represent a crucial instrument for rethinking assessment in China as the country transitions from a closed regime towards a hegemonic capitalistic power. China still maintains a certain distance from PISA, through uncertainty regarding its participation, the limited disclosure of information, alternating which regions participate in the tests, and its suspicious view of PISA's results even when extremely positive. All of this reinforces China's bargaining position and its relative autonomy from the OECD.

\section{Concluding remarks}

China entered the global economic competition late. Rather quickly, it has not only caught up, but set a challenging pace of growth. China also joined PISA later than other countries. Yet, its involvement in PISA was strategic, relied on a distinct approach of administering tests only in particular regions, and positioned China straight at the top.

Despite being a global economic power, China's society remains unequal. Participating in PISA with data from the entire country would prove costly to China's reputation, particularly after the prestige achieved by Shanghai. Thus, we conclude that instead of passively acquiescing to the world culture, China's decisions rely on contingent convergence, structural coupling, and skillful recontextualization, whereas 
China "selectively appropriate[s], relocate[s], refocus[es], and recombine[s]" (Sum, 2009:191) global and local discourses. On the one hand, China recognizes the value of ILSAs for its reputation and standing in the world, adopting them as a specific set of capital to break the East-West dichotomy and to strengthen its competitiveness in the globalized knowledge economy. On the other hand, as an empowered state, China adjusts its participation in PISA to serve its own political agenda, taking advantage of its wealthier regions. China internationalizes at a fast pace, selectively globalizing what it deems relevant. Its successful PISA performance increases the Chinese volume of capital globally, serving as a successful strategy to increase China's reputation and influence internationally. Thus, we infer that China's PISA results stem from a political construction (to serve China's goals) rather than representing Chinese education as a whole.

China seems to be testing different ways of participating in PISA to obtain different rewards (e.g., legitimizing reforms undertaken prior to the test, supporting additional reforms, and boosting national sentiments), since PISA may be used to disguise or emphasize problems. By recognizing the value of ILSAs for its global reputation and standing, and by shaping its relationship with the OECD in a unique manner, China takes advantage of its participation in PISA by controlling the knowledge produced by the indicator. Information control avoids the politicization of competing interests (e.g., media, population, and international organizations), whereas "playing" with PISA remains a political game of maximizing gains and minimizing losses for China. PISA functions as a tool to glorify Chinese education and legitimize reforms, and to scandalize practices that seem unfit for the globalized knowledge economy, thereby justifying reforms. Thus, China acts in a glocalized fashion: it assumes the role of a determining and empowered agent who enacts and reinforces the 
global scripts diffused through PISA. This resonates with the Chinese plan to take agency to "reform and improve the international economic governance system" to "actively guide the international economic agenda" (China, 2016, Chapter 52). Our study, therefore, reinforces the idea that global scripts "move and morph" (Cowen, 2009), thus, are locally constructed (Steiner-Khamsi, 2019).

The engagement of China in PISA has professionalized its political processes through increased evidence-based policymaking, contributed to building its technical capacity to assess its own education system and develop domestic large-scale assessments, which also legitimized and promoted national political agendas. In addition, PISA provided international visibility to China and to its pedagogical innovations, fostered international relations, and corroborated the adoption of the "economistic logic" in the country associated with modernization and with a human capital supply. Diverging from Addey et al. (2017), however, the participation of China in PISA is not associated with receiving funding and aid. China needs neither funding nor aid - it is rather a funder and donor of economic capital. But, following our Bourdieusian approach, instead of demanding financial resources, China's participation in PISA relates to the demand for other types of capital. Such capital includes the technical capacity for developing its own assessment system, social capital to enhance its interaction with other global players, symbolic capital manifested through recognition, reputation, and prestige, as well as political capital to become a more influential global actor. Therefore, China's participation in PISA symbolizes the accumulation of certain types of "legitimate" capital, the volume of which is relevant for obtaining power and competing in the globalized knowledge economy. Such capital is also crucial for enabling a smooth fusion of East and West norms in education as well as in economics and politics, since PISA, the polyglot instrument, easily transmits 
information across different fields.

This article fostered discussions in the field of Comparative Education research, portraying China as a self-motivated and active agent rather than a passive recipient of international policies emanating from transnational organizations. We view China's participation in PISA as a component of the country's broader political project, which benefits from the accumulation of capital and power through the enactment of global scripts in a glocalized fashion. This broader project consists of China's strong position in technological manufacturing, ambitious infrastructure projects (e.g., the construction of a polar railway), massive foreign investment abroad (e.g., in Africa), and ranking well on international indicators. Such a political project reflects the intertwinement of different types of capital to enhance China's competitiveness in the globalized knowledge economy. As Bourdieu (2003) explained, the total capital consists of different proportions of each of the legitimate types of capital, the value of which lies in strategies and "bets" employed in the struggles among agents resembling a game in which each player has a pile of poker chips of different colors. The bigger the pile of chips (in terms of the number of chips and composition vis-à-vis the most "legitimate" colors), the more audacious the game. Analogously, participation in PISA is insufficient in terms of accumulating capital, since the most distinctive capital is conferred only to top performers. Rather than a passive player in such a game, China exercised its agency to influence the rules. It determines which parts of the country participate in the PISA tests and which results are disclosed. China both accepts global scripts and subverts them, thereby also influencing their development: it has selectively engaged in PISA, and PISA has been transformed to reflect the regional diversity within countries. Thus, rather than arbitrarily constructed, as some may claim (at least, this was the tone in some articles about China's participation in PISA), ILSAs mutually constitute and are 
constituted by knowledge and power.

Analyzing China's engagement in PISA provided answers to our questions about such a distinctive participation, but raised many others. One of them concerns how the capital accumulated through high PISA rankings is being invested in global (or domestic) arenas. Other questions refer to the effects of opting-out and withdrawing from participation in ILSAs. The literature tends to concentrate on examples of successful and rewarding engagements in ILSAs, although rarely regards outliers who lose rather than gain from their involvement in ILSAs, and those who truly lie beyond the international testing regime. We contend that our study provides fertile ground for further research, since China is an exceptionally interesting case as a country that is both "in" and "out" of PISA in many senses. However, we recommend additional analyses of Chinese data (e.g., data collected through interviews in China) to address this topic and the regional (subnational) dynamics of PISA in countries like China. We wonder to what extent PISA contributes to the creation of a new identity for China. Simultaneously, China seems to contribute to the reinvention of the identity of PISA.

\section{References}

Akbik, A.; Martens, K.; Zhang, C. (2014) Joining the World of Education? China's Reaction to Internationalisation Pressures. In: Martens, K.; Knodel, P.; Windzio, M. Internationalization of Education Policy - A New Constellation of Statehood in Education. Palgrave McMillan, 224-244.

Addey, C.; Sellar, S.; Steiner-Khamsi, G.; Lingard, B.; Verger, A. (2017) The rise of international large-scale assessments and rationales for participation. Compare: A Journal of Comparative and International Education, 47(3), 434-452.

Auld, E.; Morris, P. (2016) PISA, policy and persuasion: translating complex conditions into education 'best practice'. Comparative Education, 52(2), 202-229. 
Ball, S. (2012) Global Education Inc.: new policy networks and the neo-liberal imaginary. Abingdon: Routledge.

Bourdieu, P. (1985) The social space and the genesis of groups. Theory and Society, 14(6), 723-744.

Bourdieu, P. (1986) The forms of capital. In: Richardson, J. (ed.) Handbook of Theory and Research for the Sociology of Education. New York: Greenwood, 241-258.

Bourdieu, P. (2003) Questões de sociologia. Lisboa: Fim de Século.

Bourdieu, P. (2014) On the State - Lectures at the College de France, 1989-1992. Polity Press.

Candido, H. H. D.; Acosta, F. (2019) Building political sustainability through PISA in Argentina. 62nd Annual Conference of the Comparative and International Education Society (CIES), San Francisco, USA.

CEIC (n.d.) China Gross Domestic Product: per Capita. Retrieved from https://www.ceicdata.com/en/china/gross-domestic-product-per-capita/grossdomestic-product-per-capita.

Chen, J. (2016) 经合组织发布最新国际学生评估项目测试报告 中国大陆排名下 滑 [OECD released the latest international student assessment report]. Xinhua News Agency. Retrieved from http://www.gov.cn/xinwen/201612/07/content_5144617.htm.

Chen, J.; Fang, F.; Hou, W.; Li, F.; Pu, M.; Song, M. (2015) Chinese Gini Coefficient from 2005 to 2012. Journal of Applied Mathematics, 1-16.

China (2016). The 13th Five-Year Plan for Economic and Social Development of the People's Republic of China (2016-2020). Beijing: Compilation and Translation Bureau, Central Committee of the Communist Party of China.

Cook, C. (2010) Shanghai tops global state school rankings. Financial Times, 7 December 2010. Retrieved from https://www.ft.com/content/20770bf6-01e711e0-b66c-00144feabdc0.

Coughlan, S. (2014) Pisa tests to include many more Chinese pupils. Retrieved from https://www.bbc.com/news/education-28937662.

Cowen, R. (2009) The transfer, translation and transformation of educational processes: and their shape-shifting? Comparative Education 45(3), 315-327.

Dahlman, C.; Zhihua Zeng, D.; Wang, S. (2007) Enhancing China's Competitiveness through Lifelong Learning. Washington D.C.: World Bank. 
Dong, C. (2013) 上海PISA项目组负责人:PISA让我们自信也让我们自省 [Head of Shanghai PISA Project Team: PISA makes us confident and let us reflect] Retrieved from http://sh.eastday.com/m/20131204/u1a7809993.html.

Dronkers, J. (2015) Are the PISA Data for Shanghai Flawed? Huffington Post, 2 October 2015. Retrieved from: https://www.huffingtonpost.com/jaapdronkers/are-the-pisa-data-for-sha_b_8234836.html.

Drori, G. S.; Höllerer, M. A.; Walgenbach, P. (2014) The Glocalization of Organization and Management. Issues, Dimensions, and Themes. In: Drori, G. S.; Höllerer, M. A.; Walgenbach, P. Global Themes and Local Variations in Organization and Management. Perspectives on Glocalization. New York: Routledge, 3-23.

Foshan Education (2016) 【两会】中国教育总体水平进入世界中上行列, 教育部长 袁贵仁答记者问 [Second Session. The overall level of China's education has joined the upper and middle ranks of the world. The Minister of Education Yuan Guiren responds to reporters]. Retrieved from http://www.sohu.com/a/63097735_355835.

Foucault, M. (2005) The hermeneutics of the subject. Basingstoke: Palgrave MacMillan.

Foucault, M. (1989) The Archaeology of Knowledge. London: Routledge.

Foucault, M. (1980) Truth and power. In: Gordon, C. (ed.) Power/Knowledge. Selected interviews and other writings 1972-1977. New York: Pantheon Books, 109-133.

Gao, S.; Yang, M.; Wang, X.; Min, W.; Rozelle, S. (2018) Peer relations and dropout behavior: Evidence from junior high school students in northwest rural China. International Journal of Educational Development, 65, 134-143.

Global Data Lab (n.d.) Subnational Human Development Index (SHDI-2.2). Retrieved from https://hdi.globaldatalab.org/areadata/shdi/.

Greckhamer, T.; Cilesiz, S. (2014) Rigor, Transparency, Evidence, and Representation in Discourse Analysis: Challenges and Recommendations. International Journal of Qualitative Methods, 13 (1), 422-443.

Grek, S. (2009) Governing by numbers: the PISA 'effect' in Europe. Journal of Education Policy, 24(1), 23-37.

Gumbel, P. (2010) China Beats Out Finland for Top Marks in Education. Times, 7 December 2010. Retrieved from 
http://content.time.com/time/world/article/0,8599,2035586,00.html\#ixzz17XAC $\mathrm{d} 2 \mathrm{~S} 2$.

Gurova, G.; Candido, H. H. D.; Zhou, X. (2018). Effects of quality assurance and evaluation on schools' room for action. In: Kauko, J.; Rinne, R.; Takala, T. (eds.) Politics of Quality in Education: a comparative study of Brazil, China, and Russia. Routledge, 137-160.

Han, J.; Zhao, Q.; Zhang, M. (2016) China's income inequality in the global context. Perspectives in Science, 7, 24-29.

Hood, C.; Jackson, M. (1991) Administrative argument. Aldershot: Dartmouth. Jerrim, J.; Shure, N. (2016) Achievement of 15-Year-Olds in England: PISA 2015 National Report. Retrieved from https://www.gov.uk/government/publications/pisa-2015-national-report-forengland.

Jiefang Ribao (2013) PISA上海项目组负责人：学习时间与成绩成正比例 [PISA Shanghai Project Team Leader: Learning Time and Proportionality]. Retrieved from http://blog.sina.com.cn/s/blog_519169510101j3iz.html.

Kanbur, R.; Zhang, X. (1999) Which Regional Inequality? The Evolution of RuralUrban and Inland-Coastal Inequality in China from 1983 to 1995. Journal of Comparative Economics, 27, 686-701.

Li, D.; Lu, D. (2016) Mapping population density distribution at multiple scales in Zhejiang Province using Landsat Thematic Mapper and census data. International Journal of Remote Sensing, 37(18), 4243-4260.

Li, S.; Sato, H.; Sicular, T. (2013) Rising inequality in China: Challenges to a harmonious society. Cambridge University Press.

Loveless, T. (2014) How well are American students learning? With sections on the PISA-Shanghai Controversy, Homework, and the Common Core. Washington, D.C.: The Brookings Institution.

Lu, M.; Cui, M.; Shi, Y.; Chang, F.; Mo, D.; Rozelle, S.; Johnson, N. (2016) Who drops out from primary schools in China? Evidence from minority-concentrated rural areas. Asia Pacific Education Review, 17(2), 2325-252.

Ma, L. (2010) The Making of the Chinese Working Class: Rural Migrants in Shanghai. Dissertation presented to the Faculty of the Graduate School of Cornell University. Retrieved from 
https://ecommons.cornell.edu/bitstream/handle/1813/17648/Ma\%2C\%20Li.pdf? sequence $=1 \&$ is Allowed $=\mathrm{y}$.

Meyer, J. W.; Boli, J.; Thomas, G. M.; Ramirez, F. O. (1997) World Society and the Nation-State. The American Journal of Sociology, 103(1), 144-81.

MOE (2013) 经合组织全球统一发布 2012 , PISA测试结果上海又获数学阅读科学三 项第一 [PISA Results from the OECD: math, reading and science are ranked n.1 again in Shanghai]. Retrieved from http://www.moe.gov.cn/jyb_xwfb/s5147/201312/t20131204_160391.html.

MOE (2015) 我国建立义务教育质量监测制度, 今年起开展监测工作一一中国特色 “PISA”揭开面纱 [Our Country Builds the Quality Monitoring System for Compulsory Education]. Retrieved from http://www.moe.gov.cn/jyb_xwfb/xw_fbh/moe_2069/xwfbh_2015n/xwfb_1504 15/150415_mtbd/201504/t20150416_187197.html.

MOE (2018) 切实担负好国家教材建设的历史使命, 200余名专家委员会委员正式“ 上岗”, 国家教材委员会专家委员会工作研讨会召开 [Implementing and taking responsibility of the construction of country's education as a historical mission]. Retrieved from http://www.moe.gov.cn/jyb_xwfb/gzdt_gzdt/moe_1485/201805/t20180523_336 822.html.

National Bureau of Statistics of China (2017) Income of Shanghai and Beijing.

Retrieved from http://data.stats.gov.cn/easyquery.htm?cn=E0105.

OECD (2010a) PISA 2009 at a Glance. OECD Publishing. Retrieved from http://dx.doi.org/10.1787/9789264095298-en.

OECD (2010b) Shanghai and Hong Kong: Two Distinct Examples of Education Reform in China. Retrieved from https://www.oecd.org/countries/hongkongchina/46581016.pdf.

OECD (2012a) Shanghai and Hong Kong: Learning to Lean. Retrieved from https://www.oecd-ilibrary.org/docserver/9789264118539en.pdf?expires $=1550400870 \& \mathrm{id}=\mathrm{id} \&$ ac $\mathrm{cname}=$ guest $\&$ checksum $=9 \mathrm{EC} 1 \mathrm{C} 64 \mathrm{~A} 0$ A4195A5E2B37EC359BACF0A.

OECD (2012b) PISA 2009 Technical Report. Retrieved from https://www.oecd.org/pisa/pisaproducts/50036771.pdf. 
OECD (2014a) PISA 2012 Results in Focus. Retrieved from https://www.oecd.org/pisa/keyfindings/pisa-2012-results-volume-I.pdf.

OECD (2014b) OECD and China expand cooperation in PISA education programme. Retrieved from http://www.oecd.org/education/oecd-and-china-expandcooperation-in-pisa-education-programme.htm.

OECD (2016a) PISA 2015 High Performers. Country Note - China. Retrieved from https://www.oecd.org/pisa/PISA-2015-china.pdf.

OECD (2016b) PISA 2015 Results (Volume I): Excellence and Equity in Education. Paris: OECD Publishing.

OECD (2016c) Education in China: a snapshot. Retrieved from https://www.oecd.org/china/Education-in-China-a-snapshot.pdf.

OECD (2017) PISA 2015 Technical Report. Retrieved from http://www.oecd.org/pisa/data/2015-technical-report/.

OECD (2018) PISA 2015 Results in Focus. Retrieved from https://www.oecd.org/pisa/pisa-2015-results-in-focus.pdf.

OECD (2019). PISA 2018 Results (Volume I): What Students Know and Can Do. Paris: OECD Publishing.

OECD (n.d.) Programme for International Student Assessment (PISA). Retrieved from http://www.oecd.org/pisa/.

Osborne, D.; Gaebler, T. (1993) Reinventing government: how the entrepreneurial spirit is transforming the public sector. Reading, MA: Addison-Wesley.

Ozga, J. (2009) Governing education through data in England: from regulation to selfevaluation. Journal of Education Policy, 24(2), 149-162.

Popkewitz, T. S.; Brennan, M. (1998) Restructuring of social and political theory in education. In: Popkewitz, T. S.; Brennan, M. (eds) Foucault's challenge. New York: Teachers College Press, 3-35.

Qiang, L.; An, L.; Tan, J.; Zheng, C.; Yang, M.; Gong, C. (2017) School Dropout, Ethnicity and Religion: Evidence from Western Rural China. The Chinese Economy, 50(3), 193-204.

Rautalin, M.; Alasuutari, P. (2009) The uses of the national PISA results by Finnish officials in central government. Journal of Education Policy, 24(5), 539-556.

Reder, T. J. (2018) The OECD \& Non-Member States in the Field of Education. European Conference on Educational Research (ECER), Bolzano, Italy. 
Reyes, V.; Tan, C. (2019) PISA and Self-Projection in Shanghai. In: Waldow, F.;

Steiner-Khamsi, G. Understanding PISA's Attractiveness: Critical Analyses in Comparative Policy Studies. Bloomsbury Academic, 161-176.

Robertson, R. (1992) Globalization: Social Theory and Global Culture. London: SAGE.

Robertson, R. (1995) Glocalization: Time-Space and Homogeneity-Heterogeneity. In:

Featherstone, M.; Lash, S.; Robertson, R. Global Modernities. London: SAGE, $25-44$.

Sands, G. (2017) Are The PISA Education Results Rigged? Forbes, 4 January 2017.

Retrieved from: https://www.forbes.com/sites/realspin/2017/01/04/are-the-pisaeducation-results-rigged/\#17c3a92b1561.

Schleicher, A. (2013) Are the Chinese cheating in PISA or are we cheating ourselves?

Retrieved from http://oecdinsights.org/2013/12/10/are-the-chinese-cheating-inpisa-or-are-we-cheating-ourselves/\#comments.

Schreier, M (2012) Qualitative Content Analysis in Practice: SAGE.

Schulte, B. (2019) Curse or Blessing? Chinese Academic Responses to China's PISA Performance. In: Waldow, F.; Steiner-Khamsi, G. Understanding PISA's Attractiveness: Critical Analyses in Comparative Policy Studies. Bloomsbury Academic, 177-197.

Sellar, S.; Lingard, B. (2013) Looking East: Shanghai, PISA 2009 and the Reconstitution of Reference Societies in the Global Education Policy Field. Comparative Education, 49(4), 464-485.

Shanghai (n.d.) Population. Retrieved from http://www.shanghai.gov.cn/shanghai/node23919/node24059/node24062/userob ject22ai36496.html.

Simons, J. (1995) Foucault and the Political. London: Routledge.

Spence, J. D. (1990) The Search for Modern China. New York/London: Norton.

Steiner-Khamsi, G. (2003) The politics of league tables. Online Journal for Social Sciences and their Didactics, 1, 1-6.

Steiner-Khamsi, G. (2019) What Policy-Makers Do with PISA. In: Waldow, F.; SteinerKhamsi, G. Understanding PISA's Attractiveness: Critical Analyses in Comparative Policy Studies. Bloomsbury Academic, 233-248.

Strauss, V. (2013) Did Shanghai cheat on PISA? Washington Post, 15 December 2013. Retrieved from: https://www.washingtonpost.com/news/answer- 
sheet/wp/2013/12/15/did-shanghai-cheat-on-

pisa/?noredirect=on\&utm_term $=$. a116e $4 \mathrm{cf} 345 \mathrm{a}$.

Sum, N.-L. (2009) The Production of Hegemonic Policy Discourses: 'Competitiveness' as a Knowledge Brand and Its (Re-)Contextualizations. Critical Policy Studies, 3(2), 184-203.

Takala, T.; Kallo, J.; Kauko, J.; Rinne, R. (2018) One Size for All? Policy Advice of the World Bank and the OECD on Quality Assurance and Evaluation of School Education in Russia, Brazil, and China. In: Wiseman, A. W.; Davidson, P. M. Cross-nationally Comparative, Evidence-based Educational Policymaking and Reform. International Perspectives on Education and Society, Vol. 35. Emerald Publishing Limited, 301-319.

Takayama, K.; Waldow, F.; Sung, Y-K. (2013) Finland has it all? Examining the media accentuation of 'Finnish Education' in Australia, Germany and South Korea. Research in Comparative and International Education, 8(3), 307-325.

Tan, C. (2017) PISA and education reform in Shanghai. Critical Studies in Education. Retrieved from https://www.tandfonline.com/doi/abs/10.1080/17508487.2017.1285336?journal Code $=$ rcse20.

UN (n.d.) World Population Prospects 2017. United Nations. DESA/ Population Division. Retrieved from https://population.un.org/wpp/.

Wacquant, L. (2007) Reading Bourdieu's “capital”. Educação \& Linguagem, 16, 37-62. Waldow, F.; Steiner-Khamsi, G. Understanding PISA’s Attractiveness: Critical Analyses in Comparative Policy Studies. Bloomsbury Academic.

Walker, M. (2011) PISA 2009 Plus Results: Performance of 15-year-olds in reading, mathematics and science for 10 additional participants. Melbourne: ACER Press.

Wang, J. (2013) PISA后上海将推自己评价体系——"绿色指标" [After PISA, Shanghai will push its own evaluation system - "green indicator"]. Retrieved from http://sh.eastday.com/m/20131204/u1a7809994.html.

Wang, W. (2014) 上海或将退出下次PISA测试 [Shanghai may withdraw from the next PISA test] Xinmin Evening News. Retrieved from https://www.ecnu.edu.cn/_s64/b2/5e/c1835a45662/page.psp. 
WB (n.d.) Rural population. The World Bank Data. Retrieved from https://data.worldbank.org/indicator/SP.RUR.TOTL.ZS.

Wilkins, A. (2016) Modernising School Governance. London: Routledge.

Xu, D.; Wu, X. (2016) Separate and Unequal: Hukou, School Segregation, and Migrant Children's Education in Urban China. University of Michigan Institute for Research: Population Studies Center.

Zhang, C.; Akbik, A. (2012) PISA as a Legitimacy Tool during Education Reform: Case Study of Shanghai. TranState Working Papers, 166. Bremen: Sfb 597 „Staatlichkeit im Wandel“.

Zhang, W. (2013) An Analysis of China's Education Resources Allocation and its Policy Choice-Measurement of Education based on Gini Coefficient. Journal of Renmin University of China, 4. Retrieved from http://ww2.usc.cuhk.edu.hk/PaperCollection/webmanager/wkfiles/2012/9251_1 _paper.pdf. 